\title{
Analisis Tingkat Kognitif Soal Pada Modul Pengayaan Matematika Kelas VII Semester II Terbitan Putra Nugraha Berdasarkan Taksonomi Bloom Revisi
}

\author{
Fentiriani Fauzi, Hari Sumardi, Hanifah
}

\section{(C) 2021 JEMS (Jurnal Edukasi Matematika dan Sains)}

This is an open access article under the CC-BY-SA license

(https://creativecommons.org/licenses/by-sa/4.0/) ISSN 2337-9049 (print), ISSN 2502-4671 (online)

\begin{abstract}
Abstrak:
Penelitian ini bertujuan untuk mengetahui sebaran tingkat kognitif soal pada Bab Garis dan Sudut dan Bab Segi Empat dan Segitiga pada Modul Pengayaan Matematika Kelas VII Semester II terbitan Putra Nugraha berdasarkan Taksonomi Bloom Revisi. Jenis penelitian ini adalah penelitian deskriptif dengan pendekatan kualitatif. Sumber data penelitian pada penelitian ini adalah soal pada Bab Garis dan Sudut dan Bab Segi Empat dan Segitiga pada Modul Pengayaan Matematika Kelas VII Semester II terbitan Putra Nugraha. Metode yang digunakan adalah observasi dan dokumentasi. Soal-soal yang dianalisis berjumlah 96 soal. Pada Bab Garis dan Sudut dengan 47 soal terklasifikasi $\mathrm{C} 1$ sebanyak 4 soal $(8,5 \%)$, C2 sebanyak 22 soal $(46,8 \%)$, C3 sebanyak 21 soal $(44,7 \%)$, sedangkan untuk C4 (Menganalisis), C5 (Mengevaluasi), dan C6 (Mencipta) tidak ada. Pada Bab Segi Empat dan Segitiga terklasifikasi C1 sebanyak 6 soal $(12,2 \%)$, C2 sebanyak 4 soal $(8,2 \%)$, C3 sebanyak 39 soal $(79,6 \%)$, dan C4 (Menganalisis), C5 (Mengevaluasi), dan C6 (Mencipta) tidak ada.
\end{abstract}

Kata Kunci :Modul Pengayaan; Matematika;Taksonomi Bloom Revisi; Tingkat Kognitif.

\begin{abstract}
:
The aim of this research was to determine the distribution of cognitive levels on questions of Lines and Angles and Quadrilateral and Triangle chapter in the Enrichment Module of Mathematics Published by Putra Nugraha Grade VII on even semester based on Revised Bloom Taxonomy. This type of research was descriptive research with a qualitative approach. Sources of research data in this research were questions of Lines and Angles and Rectangle and Triangle chapter in the Enrichment Module of Mathematics published by Putra Nugraha Grade VII on Even Semester. The methode used are observation and documentation. The questions had 96 questions. The questions of Lines and Angles had cognitive levels of $\mathrm{C} 1$ as many as 4 questions $(8,5 \%), \mathrm{C} 2$ as many as 22 questions (46,8\%), C3 as many as 21 questions $(44,7 \%)$, and for C4 (analyzing), C5 (evaluating), dan C6 (creating) don't exist. The questions of Rectangle and Triangle had cognitive levels of $\mathrm{C} 1$ as many as 6 questions (12,2\%), C2 as many as 4questions $(8,2 \%), \mathrm{C} 3$ as many as 39 questions $(79,6 \%)$, and for C4 (analyzing), C5 (evaluating), dan C6 (creating) don't exist.
\end{abstract}

Keywords: Enrichment Module; Mathematics; Revised Bloom Taxonomy; Cognitive Level.

\section{Pendahuluan}

Salah satu mata pelajaran yang mempunyai peranan penting dalam pendidikan adalah Matematika. Secara tidak sadar Matematika selalu ada disekitar kita sehingga Matematika mempunyai peranan penting dalam kehidupan manusia (Ambar \& Uswatun, 2018). Misalnya dalam melakukan jual beli. Tentunya konsep dasar seperti penjumlahan, pengurangan, perkalian, dan pembagian akan digunakan.

Dalam mempelajari matematika dibutuhkan pemikiran logis serta penalaran yang menjadikan matematika sebagai salah satu pelajaran yang kurang diminati siswa. Kurangnya minat dalam mempelajari matematika dapat menyebabkan siswa kesulitan dalam memahami konsep matematika. Oleh karena itu, guru harus menggunakanbahan ajar

Fentiriani Fauzi, Universitas Bengkulu

fenti72@gmail.com

Hari Sumardi, Universitas Bengkulu

harisumardi@unib.ac.id

Hanifah, Universitas Bengkulu

hanifah@unib.ac.id 
yang sesuai yang dapat menuntun siswa dalam memahami konsep dengan baik sehingga dapat menyelesaiakan soal-soal matematika yang diberikan.

Bahan ajar yang biasa digunakan dalam pembelajaran matematika di sekolah salah satunya adalah buku teks matematika terbitan Kemendikbud yang disebarluaskan secara gratis baik secara cetak maupun BSE (Buku Sekolah Elektronik). Buku teks pelajaran adalah salah satu alat atau sumber pembelajaran yang penting dalam menunjang efektivitas pembelajaran. Dalam Peraturan Pemerintah Nomor 32 Tahun 2013 tentang Standar Nasional Pendidikan pasal 1 ayat 23 disebutkan bahwa buku teks merupakan sumber belajar utama untuk mencapai kompetensi dasar dan kompetensi isi. Di sekolah, umumnya buku teks yang dipakai menggunakan kurikulum 2013 edisi revisi 2017 dengan pendekatan saintifik. Pada kurikulum 2013, materi dibuat secara seimbang antara kompetensi sikap, pengetahuan dan keterampilan. Pendekatan pembelajaran berbasis observasi, pengumpulan data, penalaran, dan penyajian hasil melalui pemanfaatan berbagai sumber belajar (Widyaharti, et al., 2015). Selain buku tersebut, beberapa sekolah juga mengunakan buku tambahan dalam memperdalam pemahaman siswa yang disebut sebagai buku pendamping seperti Modul Pengayaan.

Modul adalah paket belajar mandiri yang mencakup serangkaian kegiatan belajar yang direncanakan dan dirancang secara sistematis untuk mencapai tujuan pembelajaran (Setiyadi, et al., 2017; Lasmiyati \& Harta, 2014). Modul Pengayaan adalah bahan ajar yang dapat menjadikan peserta didik belajar aktif secara mandiri. Menurut Winkel, Modul Pengayaan adalah unit terkecil dari program belajar mengajar, yang dipelajari oleh siswa sendiri secara individu atau diajarkan oleh siswa untuk dirinya sendiri (self-instructional) (Ihtifazhuddan, et al., 2018). Pada modul pengayaan terdapat ringkasan materi, rumus dan latihan - latihan soal yang disediakan dalam menunjang pembelajaran sebagai buku pendamping dari buku teks yang disediakan. Modul pengayaan juga sering disebut sebagai buku pengayaan. Buku pengayaan adalah buku yang memuat materi yang mengacu pada kurikulum yang berlaku (Alfarisi, 2019).

Berdasarkan pengalaman Magang II di SMPN 14 Kota Bengkulu yang dilaksanakan dari tanggal 5 Oktober 2020 hingga 7 Desember 2020, siswa diberikan buku pendamping berupa Modul Pengayaan terbitan Putra Nugraha. Hal tersebut dilakukan untuk membantu siswa dalam menyelesaikan lebih banyak soal yang bervariasi yang disediakan di dalam Modul Pengayaan tersebut. Pada Modul Pengayaan ini terdapat Tugas Mandiri, Tugas Rumah, Uji Kompetensi, Tugas Aktif dan Kreatif, dan Perbaikan. Namun soal yang terdapat pada modul pengayaan ini belum diketahui mengenai sebaran tingkat kognitifnya. Oleh karena itu, perlunya dilakukan pengkajian tentang sebaran tingkat kognitif soal pada Modul Pengayaan terbitan Putra Nugraha dengan menggunakan Taksonomi Bloom Revisi.

Taksonomi Bloom adalah struktur yang digunakan dalam pengkatagorian soal untuk mengetahui kesesuaian soal dalam mengukur kemampuan siswa. Didalam taksonomi pendidikan, ranah yang digunakan adalah ranah kognitif. Demi mengimbangi kemajuan zaman maka dilakukan revisi oleh Anderson \& Krathwohl dengan nama Taksonomi Bloom Revisi (Anderson \& Krathwohl, 2010). Ranah kognitif direvisi menjadi dua dimensi yaitu dimensi pengetahuan kognitif dan dimensi proses kognitif. Berdasarkan hasil revisi tersebut terdapat empat kategori dalam dimensi pengetahuan kognitif yaitu: (1) pengetahuan faktual; (2) pengetahuan konseptual; (3) pengetahuan prosedural; dan (4) pengetahuan metakognitif. Sedangkan pada dimensi proses kognitif dibagi menjadi 6 tingkatan yaitu: (1) mengingat (remembering); (2) memahami (understanding); (3) mengaplikasikan (applying); (4) menganalisis (analyzing); (5) mengevaluasi (evaluating); dan (6) mengkreasi (creating) (Effendi, 2017; Islah, et al., 2019). Semua tingkatan tersebut merupakan proses pengkatagorian proses kognitif yang bertujuan untuk membantu pendidik (termasuk pembuat tes) dalam memperluas assement pembelajaran (Anderson \& Krathwohl, 2010). 
Dengan menggunakan Taksonomi Bloom ini, dapat ditentukan level soal yang sesuai dengan keadaaan siswa.

\section{Metode}

Jenis penelitian yang digunakan pada penelitian ini adalah penelitian deskriptif dengan pendekatan kualitatif. Penelitian ini termasuk penelitian deskriptif dikarenakan dalam penelitian ini dilakukan analisis untuk menggambarkan atau mendeskripsikan tingkatan Taksonomi Bloom yaitu dimensi proses kognitif pada soal mata pelajaran Matematika. Metode penelitian kualitatif berdasarkan falsafah postpositivisme, digunakan untuk mengkaji kondisi objek alam, dimana peneliti sebagai instrumen kunci, pengambilan sampel sumber data dilakukan secara purposive dan snowball, triangulasi (gabungan) teknik pengumpulan, analisis data bersifat induktif/kualitatif, dan hasil penelitian kualitatif lebih menekankan pada makna daripada generalisasi (Sugiyono, 2016). Selain itu, penelitian ini untuk mendeskripsikan persentase di setiap tingkatan Taksonomi Bloom pada setiap soal.

Adapun prosedur penelitian yang akan dilakukan adalah sebagai berikut:

1. Mengidentifikasi soal Bab Garis dan Sudut dan Bab Segi Empat dan Segitiga pada Modul Pengayaan Matematika Kelas VII Semester II terbitan Putra Nugraha yang ditulis oleh Adkha Masita.

2. Melakukan penyelesaian terhadap soal Bab Garis dan Sudut dan Bab Segi Empat dan Segitiga pada Buku Pendamping Matematika Kelas VII Semester II terbitan Putra Nugraha yang ditulis oleh Adkha Masita.

3. Mendeskripsikan setiap kemampuan kognitif yang digunakan dalam penyelesaian soal tersebut.

4. Menggolongkan tingkat kognitif untuk masing-masing kemampuan kognitif yang muncul dalam penyelesaian soal tersebut berdasarkan tingkat kognitif Taksonomi Bloom Revisi.

5. Melakukan analisis tingkat kognitif soal.

6. Menarik kesimpulan dan saran.

Sumber data dalam penelitian ini adalah soal-soal pada Modul Pengayaan Matematika untuk SMP/MTs Kelas VII Semester II Kurikulum 2013 terbitan Putra Nugraha yang ditulis oleh Adkha Masita. Soal-soal yang dianalisis terdapat pada Bab Garis dan Sudut sebanyak 47 soal dan Segi Empat dan Segitiga sebanyak 49 soal.

Pengumpulan data yang dilakukan dalam penelitian ini adalah menggunakan teknik dokumentasi dan observasi. Instrumen yang digunakan peneliti yaitu lembar klasifikasi yang berisi soal yang akan dianalisis, jawaban soal, dan klasifikasi kategori tingkat kognitif soal. Terdapat lembar kesesuaian yang berfungsi untuk melihat kesesuaian hasil analisis dari peneliti dan teman sejawat. Dalam pengkategorian soal berpedoman pada Tabel 1 berikut.

Tabel 1. Indikator Penentuan Tingkat Kognitif Soal

\begin{tabular}{ll}
\hline Tingkat Kognitif & Indikator \\
\hline C1. Mengingat & 1. $\begin{array}{l}\text { Meminta pendefinisian mengenai Garis, Sudut, Segi } \\
\text { Empat dan Segitiga. }\end{array}$ \\
2. $\begin{array}{l}\text { Mengingat informasi sifat-sifat mengenai Garis, } \\
\text { Sudut, Segi Empat dan Segitiga. } \\
\text { Mengenali suatu istilah yang relevan dengan konsep } \\
\text { Garis, Sudut, Segi Empat dan Segitiga. } \\
\text { 3enarik ingatan terkait konsep, prinsip dan rumus } \\
\text { mengenai Garis, Sudut, Segi Empat dan Segitiga. }\end{array}$ \\
\hline
\end{tabular}




\begin{tabular}{|c|c|}
\hline Tingkat Kognitif & Indikator \\
\hline C2. Memahami & $\begin{array}{l}\text { 1. Mengubah atau menafsirkan suatu informasi } \\
\text { menjadi bentuk lain atau model matematika. } \\
\text { 2. Menyebutkan atau menunjukkan contoh dari Garis, } \\
\text { Sudut, Segi Empat dan Segitiga. } \\
\text { 3. Mengetahui makna dari suatu informasi atau } \\
\text { gambar mengenai Garis, Sudut, Segi Empat dan } \\
\text { Segitiga. } \\
\text { 4. Menggelompokkan suatu sifat Garis, Sudut, Segi } \\
\text { Empat dan Segitiga berdasarkan informasi yang } \\
\text { diberikan. } \\
\text { 5. Merangkum informasi yang diterima. } \\
\text { 6. Menyimpulkan informasi yang diperoleh. } \\
\text { 7. Menentukan hubungan antara dua informasi atau } \\
\text { lebih. } \\
\text { 8. Menjelaskan suatu sebab-akibat dari jawaban yang } \\
\text { didapatkan. }\end{array}$ \\
\hline C3. Mengaplikasikan & $\begin{array}{l}\text { 1. Mengeksekusi proses penyelesaian suatu } \\
\text { soal/masalah yang sudah familier mengenai Garis, } \\
\text { Sudut, Segi Empat dan Segitiga. } \\
\text { 2. Memuat proses memilih dan menggunakan suatu } \\
\text { prosedur dalam menyelesaian suatu soal/masalah } \\
\text { yang tidak familier mengenai Garis, Sudut, Segi } \\
\text { Empat dan Segitiga. }\end{array}$ \\
\hline C4. Menganalisis & $\begin{array}{l}\text { 1. Memilah informasi yang penting dan relevan untuk } \\
\text { menyelesaikan soal/masalah Garis, Sudut, Segi } \\
\text { Empat dan Segitiga. } \\
\text { 2. Menentukan hubungan-hubungan yang sistematis } \\
\text { dan koheren antarpotongan informasi yang penting } \\
\text { dan relevan. } \\
\text { 3. Menentukan sudut pandang, pendapat, nilai, atau } \\
\text { tujuan dibalik informasi mengenai Garis, Sudut, Segi } \\
\text { Empat dan Segitiga. }\end{array}$ \\
\hline C5. Mengevaluasi & $\begin{array}{l}\text { 1. Memuat proses memeriksa/mendeteksi } \\
\text { kesalahan/kekeliruan dalam persoalan Garis, Sudut, } \\
\text { Segi Empat dan Segitiga. } \\
\text { 2. Memuat proses menentukan kesesuaian/ketepatan } \\
\text { suatu prosedur untuk menyelesaikan masalah Garis, } \\
\text { Sudut, Segi Empat dan Segitiga. }\end{array}$ \\
\hline C6. Membuat & $\begin{array}{l}\text { 1. Merumuskan beberapa ide/hipotesis/dugaan untuk } \\
\text { menyelesaikan soal/masalah Garis, Sudut, Segi } \\
\text { Empat dan Segitiga yang diberikan. } \\
\text { 2. Merencanakan suatu metode atau prosedur dalam } \\
\text { menyelesaikan masalah Garis, Sudut, Segi Empat } \\
\text { 3. dan Segitiga yang diberikan. } \\
\text { 4. Menghasilkan suatu produk atau konsep yang dapat } \\
\text { digunakan pada suatu soal tertentu. }\end{array}$ \\
\hline
\end{tabular}

Sumber: Modifikasi dari Anderson \& Krathwohl (2010) 
Selanjutnya menghitung presentase dari setiap tingkat kognitif berdasarkan hasil analisis soal yang telah dikelompokan tingkat kognitifnya. Kemudian menghitung korelasi hasil analisis tingkat kognitif soal berdasarkan persepsi peneliti dan teman sejawat. Dalam menghitung korelasi hasil analisis tingkat kognitif menggunakan uji Korelasi Spearman Rank yang dihitung menggunakan SPSS.

Setelah menentukan korelasi hasil analisis hasil tingkat kognitif soal berdasarkan persepsi peneliti dan teman sejawat maka dapat ditentukan tingkat keeratannya. Dalam menentukan tingkat keeratan tersebut dapat berpedoman kepada tabel Interpretasi Koefisien Korelasi berikut.

Tabel 2. Pedoman Interpretasi Koefisien Korelasi

\begin{tabular}{ll}
\hline Interval Nilai Korelasi $(\boldsymbol{\rho})$ & Tingkat Keeratan \\
\hline$\rho=0,00$ & Tidak ada \\
\hline $0,00<\rho \leq 0,20$ & Sangat rendah atau lemah sekali \\
\hline $0,20<\rho \leq 0,40$ & Rendah atau lemah, tapi pasti \\
\hline $0,40<\rho \leq 0,70$ & Cukup berarti atau sedang \\
\hline $0,70<\rho \leq 0,90$ & Tinggi atau kuat \\
\hline $0,90<\rho<1,00$ & Sangat tinggi atau kuat sekali \\
\hline$=1,00$ & Sempurna \\
\hline
\end{tabular}

Sumber : Misbahudin \& Hasan (2014)

Berdasarkan Tabel 2, apabila koefisien korelasi $(\rho)$ diperoleh minimal cukup berarti atau sedang $(0,40<\rho \leq 0,70)$, artinya hubungan dari hasil analisis tingkat kognitif soal yang dilakukan peneliti dan teman sejawat memiliki kekuatan korelasi yang cukup. Data pada penelitian yang memiliki hubungan minimal cukup, maka penelitian tersebut dikatakan absah/valid dan tidak perlu dilakukan analisis ulang.

\section{Hasil dan Pembahasan}

Hasil penelitian pada Modul Pengayaan untuk Kelas VII Semester II terbitan Putra Nugraha terdiri atas Bab Garis dan Sudut dengan 47 soal dan Bab Segi Empat dan Segitiga dengan 49 soal yang telah dianalisis tingkat kognitif berdasarkan Taksonomi Bloom Revisi. Setiap bab terdiri atas Tugas Mandiri, Tugas Rumah, Uji Kompetensi, Aktif dan Kreatif, dan Perbaikan. Adapun rincian persentase hasil analisis pada Bab Garis dan Sudut serta Bab Segi Empat dan Segitiga ditampilkan pada Tabel 3 dan Tabel 4 di bawah ini.

Tabel 3. Hasil Analisis Tingkat Kognitif Bab Garis dan Sudut

\begin{tabular}{lcc}
\hline Tingkat Kognitif & Banyak Soal & Persentase \\
\hline C1 “Mengingat" & 4 & $8,5 \%$ \\
\hline C2 “Memahami" & 22 & $46,8 \%$ \\
\hline C3 “Mengaplikasikan” & 21 & $44,7 \%$ \\
\hline C4 "Menganalisis" & 0 & $0 \%$ \\
\hline C5 “Mengevaluasi” & 0 & $0 \%$ \\
\hline C6 "Mencipta" & 0 & $0 \%$ \\
\hline Total & 47 & $100 \%$ \\
\hline
\end{tabular}


Tabel 4. Hasil Analisis Tingkat Kognitif Bab Segi Empat dan Segitiga

\begin{tabular}{lcc}
\hline Tingkat Kognitif & Banyak Soal & Presentase \\
\hline C1 "Mengingat" & 6 & $12,2 \%$ \\
\hline C2 "Memahami" & 4 & $8,2 \%$ \\
\hline C3 “Mengaplikasikan" & 39 & $79,6 \%$ \\
\hline C4 "Menganalisis" & 0 & $0 \%$ \\
\hline C5 “Mengevaluasi" & 0 & $0 \%$ \\
\hline C6 "Mencipta" & 0 & $0 \%$ \\
\hline Total & 49 & $100 \%$ \\
\hline
\end{tabular}

Dari hasil persentase diatas, maka selanjutnya dideskripsikan mengenai hasil analisis soal berdasarkan Taksonomi Bloom Revisi yang telah dilakukan oleh peneliti pada Bab Garis dan Sudut serta Bab Segi Empat dan Segitiga. Adapun deskripsi hasil analisis soal dijabarkan dengan mengambil beberapa contoh tiap tingkat kognitif sebagai berikut.

1. Soal Perbaikan (Bagian B) Nomor 1 untuk contoh soal pada tingkatan C1 (Mengingat)

\section{Sebutkan sifat-sifat jajargenjang.}

\section{Gambar 1. Soal Kategori C1 Perbaikan (Bagian B) Segi Empat dan Segitiga}

Hasil Analisis :Dalam menyelesaikan soal, siswa harus mengingat kembali (C1) sifat-sifat jajargenjang dan menyebutkannya.Berdasarkan analisis, soal ini termasuk ke dalam tingkat kognitif C1 "Mengingat".

2. Soal Uji kompetensi (Bagian A) Nomor 1untuk contoh soal pada tingkatan C2 (Memahami)

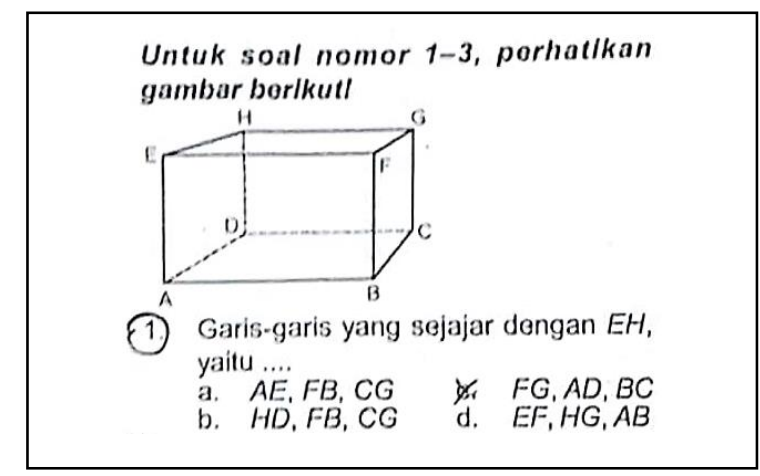

\section{Gambar 2.Soal Kategori C2 Tugas Mandiri Garis dan Sudut}

Hasil Analisis :Dalam menyelesaikan soal ini, siswa terlebih dahulu harus mengingat kembali (C1) kedudukan dua buah garis, yaitu berpotongan, sejajar, berhimpit dan bersilangan. Selanjutnya siswa harus memahami (C2) garis-garis yang memiliki kedudukan sejajar terhadap garis EH berdasarkan gambar Balok ABCD.EFGH.Dari analisis ini, disimpulkan bahwa soal tersebut termasuk ke dalam tingkat kognitif C2, yaitu "Memahami". 
3. Soal Uji Kompetensi (Bagian C) Nomor 4 untuk contoh soal pada tingkatan C3 (Mengaplikasikan)

4. Perhatikan gambar berikut.

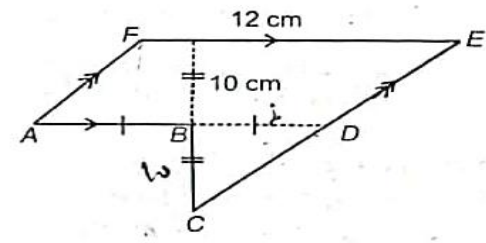

Pak Ali mempunyai kebun dengan bentuk seperti pada gambar. Kebun tersebut akan dijual dengan harga Rp200.000,00 per $\mathrm{m}^{2}$. Tentukan hasil penjualan kebun Pak Ali.

\section{Gambar 3.Soal Kategori C3 Uji Kompetensi (Bagian C) Segi Empat dan Segitiga}

Hasil analisis : Dalam menyelesaiakan soal, siswa mengenali (C1) bentuk dari gambar, yaitu bangun jajargenjang ADEF dan segitiga BCD. Selanjutnya siswa memahami (C2) informasi pada soal dan gambar, yaitu tinggi segitiga BCD sama dengan tinggi jajargenjang ADEF dan alas segitiga BCD sama dengan $1 / 2$ alas jajargenjang, serta harga Rp200.000,00 per $\mathrm{m}^{2}$ sehingga akan ditentukan luas dari bangun tersebut. Setelah itu, siswa mengeksekusi (C3) rumus Luas 1 = bangun jajargenjang ADEF, yaitu alas $x$ tinggi dan Luas 2 = segitiga $B C D$, yaitu $1 / 2$ alas $\mathrm{x}$ tinggi.Kemudian menjumlahkan kedua luas bnagun tersebut untuk menentukan luas kebun. Selanjutnya mengalikan luas kebun dan harga per $\mathrm{m}^{2}$ untuk mendapatkan hasil penjualan.berdasarkan analisis, soal ini termasuk ke dalam tingkat kognitif C3 "Mengaplikasikan".

Hasil analisis yang dilakukan Teman Sejawat memiliki beberapa soal yang tingkat kognitifnya berbeda dengan hasil analisis yang dilakukan oleh peneliti. Pada Bab Garis dan Sudut terdapat 5 soal yang berbeda $(10,6 \%)$ terdapat pada Tabel 5 dengan hasil korelasi dengan menggunakan SPSS adalah 0,832. Artinya hubungan dari hasil analisis tingkat kognitif soal yang dilakukan peneliti dan teman sejawat pada Bab Garis dan Sudut memiliki kekuatan korelasi yang tinggi sehingga data pada penelitian ini dikatakan absah/valid dan tidak perlu dilakukan analisis ulang. Pada Bab Segi Empat dan Segitiga terdapat 6 soal yang berbeda $(12,2 \%)$ terdapat pada Tabel 6 dengan hasil korelasi dengan menggunakan SPSS adalah 0,768. Artinya hubungan dari hasil analisis tingkat kognitif soal yang dilakukan peneliti dan teman sejawat pada Bab Segi Empat dan Segitiga memiliki kekuatan korelasi yang tinggi sehingga data pada penelitian ini dikatakan absah/valid dan tidak perlu dilakukan analisis ulang.

Tabel 5. Perbedaan Hasil Analisis Tingkat Kognitif pada Bab Garis dan Sudut

\begin{tabular}{llll}
\hline No & Nomor Soal & $\begin{array}{l}\text { Analisis Tingkat } \\
\text { Kognitif Soal oleh } \\
\text { Peneliti }\end{array}$ & $\begin{array}{l}\text { Analisis Tingkat } \\
\text { Kognitif Soal oleh } \\
\text { Teman Sejawat }\end{array}$ \\
\hline 1 & Tugas Rumah no. 2 & C2 (Memahami) & C3 (Mengaplikasikan) \\
\hline 2 & Uji Kompetensi (Bagian C) no. 4 & C2 (Memahami) & C3 (Mengaplikasikan) \\
\hline 3 & Uji Kompetensi (Bagian C) no. 5 & C2 (Memahami) & C3 (Mengaplikasikan) \\
\hline 4 & Perbaikan (Bagian A) no.2 & C2 (Memahami) & C3 (Mengaplikasikan) \\
\hline 5 & Perbaikan (Bagian A) no.2 & C1 (Mengingat) & C2 (Memahami) \\
\hline
\end{tabular}


Tabel 6.Perbedaan Hasil Analisis Tingkat Kognitif pada Bab Segi Empat dan Segitiga

\begin{tabular}{llll}
\hline No & Nomor Soal & $\begin{array}{l}\text { Analisis Tingkat } \\
\text { Kognitif Soal oleh } \\
\text { Peneliti }\end{array}$ & $\begin{array}{l}\text { Analisis Tingkat } \\
\text { Kognitif Soal oleh } \\
\text { Teman Sejawat }\end{array}$ \\
\hline 1 & $\begin{array}{l}\text { Uji Kompetensi (Bagian A) } \\
\text { no.10 }\end{array}$ & C2 (Memahami) & C4 (Menganalisis) \\
\hline 2 & Aktif dan Kreatif no. 3 & C2 (Memahami) & C3 (Mengaplikasikan) \\
\hline 3 & Aktif dan Kreatif no. 4 & C1 (Mengingat) & C2 (Memahami) \\
\hline 4 & Aktif dan Kreatif no. 5 & C2 (Memahami) & C5 (Mengevaluasi) \\
\hline 5 & Perbaikan (Bagian A) no.1 & C1 (Mengingat) & C2 (Memahami) \\
\hline 6 & Perbaikan (Bagian B) no.1 & C1 (Mengingat) & C2 (Memahami) \\
\hline
\end{tabular}

\section{Garis dan Sudut}

Kompetensi dasar yang diberikan pada Bab Garis dan Sudut adalah (1)Menganalisis hubungan antarsudut sebagai akibat dari dua garis sejajar yang dipotong oleh garis transversal. (2) Menyelesaikan masalah yang berkaitan dengan hubungan antar sudut sebagai akibat dari dua garis sejajar yang dipotong oleh garis transversal.Berdasarkan hasil penelitian, dapat disimpukan bahwa soal-soal pada Bab Garis dan Sudut sudah memenuhi kompetensi dasar yang ingin dicapai berdasarkan bentuk soal-soal yang telah dianalisis oleh peneliti, tetapi untuk sebaran tingkat kognitif lebih mendominan pada soal C2 (Memahami) dengan 22, C3 (Mengaplikasikan) dengan 21 soal, dan C1 (Mengingat) dengan 4 soal. Hal ini menunjukan bahwa soal-soal yang diberikan menuntut siswa dalam konsep pemahaman, dimana tingkat memahami pada Garis dan Sudut sangatlah penting sebagai langkah awal dalam menentukan penyelesaian selanjutnya yang didapatkan berdasarkan hubungan yang terbentuk, serta pengaplikasian yang dibutuhkan dalam melatih kemampuan siswa memecahkan berbagai permasalahan dengan menerapkan rumus yang ada.

Hal ini didukung oleh hasil penelitian oleh Prasetya (2017) dengan judul Analisis SoalSoal pada Buku Ajar Matematika Kelas VII Ditinjau dari Taksonomi Bloom Revisi. Pada penelitian ini didapatkan hasil untuk Bab Garis dan Sudut, yaitu C1 (Mengingat) sebanyak 9,41\%, C2 (Memahami) sebanyak 29,41\%, C3 (Mengaplikasikan) sebanyak 29,41\%,, C4 (Menganalisis) sebanyak 24,71\%, C5 (Mengevaluasi) sebanyak 1,18\%, dan C6 (Mencipta) sebanyak 1,18\%. Berdasarkan hasil tersebut, terlihat bahwa soal lebih didominasi oleh C2 (Memahami) dan C3 (Mengaplikasikan) dengan besar presentase yang sama. Sehingga pada Bab Garis dan Sudut memang menekankan siswa pada proses pemahaman dan juga pengaplikasian dalam menyelesaikan masalah yang terkait materi yang diberikan.

Sebaran kognitif yang baik untuk penilaian sebagai berikut: mengingat (C1) sebanyak $5 \%$, memahami (C2) sebanyak 10\%, mengaplikasikan (C3) sebanyak 45\%, menganalisis (C4) 25\%, mengevaluasi (C5) sebanyak 10\%, dan mencipta (C6) sebanyak 5\% (Helmawati, 2019). Berdasarkan hasil analisis, diketahui bahwa soal-soal pada Modul Pengayaan di Bab Garis dan Sudut belum memenuhi proporsi soal bahkan terdapat soal dengan presentase $0 \%$ pada C4 (Menganalisis), C5 (Mengevaluasi) dan C6 (Mencipta).Tidak ditemukannya soal-soal tersebut dikarenakan sudah termasuk ke dalam soal tingkat tinggi.

Hal ini didukung oleh hasil penelitian oleh Prasetya (2017) dengan persentase C5 dan C6 yang sangat kecil walaupun pada penelitian tersebut terdapat persentase dengan tingkat kognitif C4 yang cukup tinggi. Hal ini membuktikan bahwa soal-soal dengan tingkat kognitif tinggi masih cenderung sedikit.Selain itu, Modul Pengayaan ini ditujukan kepada siswa Kelas VII sehingga soal-soal tingkat tinggi masih jarang diberikan mengingat kemampuan dan keadaan siswa yang masih tergolong rendah.Pada Bab Garis dan Sudut, 
materi yang diberikanpun masih berkisaran dibagian pemahaman dan pengaplikasikan sederhana.

Hasil analisis tingkat kognitif berdasarkan Taksonomi Bloom oleh teman sejawat pada bab Garis dan Sudut diperoleh dari 47 soal terdapat 42 soal memiliki kesamaan tingkat kognitif soal dengan penelitian dan 5 soal memiliki perbedaan tingkat kognitifnya. Adapun penjabaran dari perbedaan analisis oleh peneliti dan teman sejawat sebagai berikut.

Soal nomor 2 pada Tugas Rumah diklasifikasikan kedalam tingkat kognitif C2 (Memahami) dikarenakan menuntut siswa untuk mengamati dan memahami hubungan antasudut dengan memperhatikan gambar untuk menentukan besar sudut yang ditanyakan dan melakukan penjumlahan untuk ketiga sudut yang ditanyakan tersebut. Sedangkan teman sejawat menklasifikasikan ke dalam tingkat kognitif C3 (Mengaplikasikan) karena melakukan proses penjumlahan pada sudut-sudut yang ditanyakan.

Soal nomor 4 pada Uji Kompetensi (Bagian C) diklasifikasikan ke dalam tingkat kognitif C2 (Memahami) dikarenakan meminta siswa untuk menentukan dan memperhatikan gambar dua buah garis sejajar yang dipotong oleh satu garis dan menafsirkan hubungan yang terbentuk menjadi bentuk persamaan untuk menentukan besar $\angle A, \angle B$, dan $\angle C$. Sedangkan teman sejawat mengkatagorikan ke dalam tingkat kogntitif C3 (Mengaplikasikan) dikarenakan siswa menerapkan prosedur operasional dalam menentukan besar $\angle \mathrm{A}, \angle \mathrm{B}$, dan $\angle \mathrm{C}$.

\section{Segi Empat dan Segitiga}

Kompetensi dasar yang diberikan pada Bab Segi Empat dan Segitiga adalah (1) Mengaitkan rumus keliling dan luas untuk berbagai jenis segiempat (persegi, persegi panjang, belah ketupat, jajargenjang, trapesium, dan layang -layang) dan segitiga (2) Menyelesaikan masalah yang berkaitan dengan keliling dan luas untuk berbagai jenis segiempat (persegi, persegi panjang, belah ketupat, jajargenjang, trapesium, dan layanglayang) dan segitiga.Berdasarkan hasil penelitian, dapat disimpukan bahwa soal-soal pada Bab Segi Empat dan Segitiga sudah memenuhi kompetensi dasar yang ingin dicapai, tetapi untuk sebaran tingkat kognitif lebih mendominan pada C3 (Mengaplikasikan) dengan 39 soal, pada C1 (Mengingat) dengan 6 soal, dan C2 (Memahami) dengan 4 soal.. Hal ini menunjukan bahwa soal-soal yang diberikan lebih menuntut siswa dalam pengaplikasian, dimana mengaplikasikan rumus luas dan keliling sangat penting dalam menyelesaikan permasalahan yang berkaitan dengan Segi Empat dan Segitiga baik dalam menentukan luas dan keliling pada gambar maupun dalam permasalahan dikehidupan sehari-hari.

Hasil tersebut didukung oleh hasil penelitian dari Efriyanti (2020) dengan judul Analisis Soal Latihan Buku Teks Matematika Kurikulum 2013 Pada Materi Segiempat dan Segitiga Berdasarkan Teori Taksonomi Bloom Revisi. Pada penelitian yang dilakukan Adelina tersebut didapatlah bahwa C1-Mengingat sebesar 3.42\% (5 butir pertanyaan), C2Memahami 18.49\% (27 butir pertanyaan), C3-Mengaplikasikan 59.60\% (87 butir pertanyaan), C4-Menganalisis 17.12 \% (25 butir pertanyaan), C5-Mengevaluasi 1,37\% (2 butir pertanyaan) dan C6-Mencipta 0\% (tidak ada sama sekali). Dari hasil tersebut, terlihat bahwa soal pada tingkat kognitif C3 (Mengaplikasikan) memang mendominasi bahkan lebih dari 50\% dari soal yang dianalisis. Sehingga menunjukkan bahwa pada materi Segi Empat dan Segitiga lebih menenkankan siswa pada proses pengaplikasian.

Sebaran kognitif yang baik untuk penilaian sebagai berikut: mengingat (C1) sebanyak $5 \%$, memahami (C2) sebanyak $10 \%$, mengaplikasikan (C3) sebanyak $45 \%$, menganalisis (C4) 25\%, mengevaluasi (C5) sebanyak 10\%, dan mencipta (C6) sebanyak 5\% (Helmawati, 2019). Berdasarkan hasil analisis, diketahui bahwa soal-soal pada Modul Pengayaan di Bab Segi Empat dan Segitiga belum memenuhi proporsi soal bahkan terdapat soal dengan presentase 
0\% pada C4 (Menganalisis), C5 (Mengevaluasi), dan C6 (Mencipta).Sedikit bahkan tidak ditemukannya soal-soal tersebut dikarenakan sudah termasuk ke dalam soal tingkat tinggi.

Hal ini juga didukung oleh penelitian yang dilakukan oleh Efriyanti (2020) bahwa untuk tingkat kognitif C4 dan C5 masih tergolong sedikit dan C6 tidak ditemukan sama sekali. Selain itu, Modul Pengayaan ini ditujukan kepada siswa Kelas VII sehingga soal-soal tingkat tinggi masih jarang diberikan mengingat kemampuan dan keadaan siswa yang masih tergolong rendah.Pada Bab Segi Empat dan Segitiga, materi yang diberikanpun lebih didominasi kedalam penerapan rumus-rumus dengan prosedur yang masih sederhana.

Hasil analisis tingkat kognitif berdasarkan Taksonomi Bloom oleh teman sejawat pada bab Segi Empat dan Segitiga diperoleh dari 49 soal terdapat 43 soal memiliki kesamaan tingkat kognitif soal dengan penelitian dan 6 soal memiliki perbedaan tingkat kognitifnya. Adapun rincian perbedaannya sebagai berikut.

Soal nomor 10 pada Uji Kompetensi (Bagian A) terklasifikasi ke dalam tingkat kognitif C2 (Memahami) dikarenakan siswa harus mengingat syarat terbentuknya suatu segitiga, yaitu jumlah kedua sisi terpendeknya lebih panjang dibanding sisi terpanjangnya, kemudian menafsirkan pilihan jawaban yang paling tepat menjadi gambar segitiga sebagai pembuktian.Sedangkan teman sejawat mengkatagorikan ke dalam tingkat kognitif C4 (Menganalisis) dikarenakan siswa diminta menganalisis pilihan jawaban yang paling tepat berdasarkan syarat terbentuknya suatu segitiga.

Soal nomor 1 pada Perbaikan (Bagian B) diklasifikasikan ke dalam tingkat kognitif C1 (Mengingat) dikarenakan meminta siswa untuk menyebutkan sifat - sifat jajargenjang.Sedangkan teman sejawatmengkatagorikan ke dalam tingkat kognitif C2 (Memahami) dikarenakan siswa diarahkan menyebutkan kembali mengenai sifat-sifat jajargenjang yang termasuk ke dalam kegiatan pemahaman bagi teman sejawat.

\section{Temuan dalam Penelitian}

Pada penelitian ini, terdapat soal dengan penggunaan kalimat yang kurang pas, sehingga membingungkan siswa dalam menjawab soal.Penjabaran mengenai soal yang bermasalah yaitu pada Soal Nomor 1 Tugas Mandiri pada Bab Garis dan sudut dibawah ini.

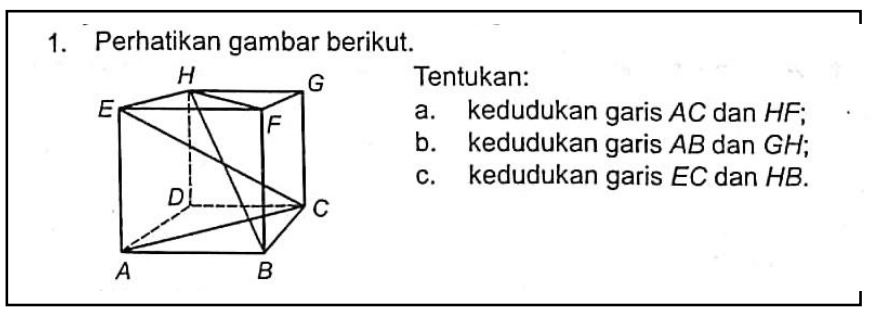

\section{Gambar 5.Soal No. 1 Tugas Mandiri Garis dan Sudut}

Pada Gambar 5, penggunaan kata yang kurang pas, yaitu kedudukan garis AC "dan" HF. Kata "dan" pada soal ini memiliki dua jawaban. Siswa akan menafsirkan bahwa soal ini mengenai kedudukan garis terhadap bidang dikarenakan kata "dan" merujuk kepada satu garis bukan mengenai hubungan kedua garis yang disebutkan pada soal; atau mengenai kedudukan dua buah garis dikarenakan setiap pertanyaan pada soal ini meminta kedudukan dua buah garis, akan tetapi penggunaan kata yang seharusnya, yaitu kedudukan garis AC "terhadap" HF sehingga terlihat hubungan mengenai kedua garis tersebut. 
2.

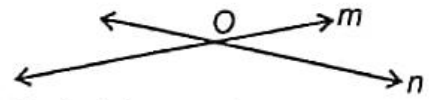

Kedudukan garis $m$ dan $n$ pada gambar di atas adalah

\section{Gambar 6. Soal No. 2 Uji Kompetensi (Bagian B) Garis dan Sudut}

Pada soal di Gambar 6 menggunakan kalimat yang sama dengan soal di Gambar 5, akan tetapi soal ini didukung dengan adanya gambar yang menunjukan bahwa soal menginginkan jawaban mengenai kedudukan dua buah garis. Dengan adanya gambar tersebut, siswa tidak akan kebingungan dalam menjawab soal.

Berdasarkan beberapa penjabaran mengenai soal-soal di atas, dapat disimpulkan bahwa pada Modul Pengayaan Matematika Kelas VII Semester II Terbitan Putra Nugraha ini memang menggunakan kata "dan" dalam pertanyaan-pertanyaan yang menginginkan jawaban mengenai kedudukan dua buah garis. Dari hasil tersebut maka soal pada Gambar 5 memang benar mengenai kedudukan dua buah garis dan dapat diselesaikan oleh siswa.

\section{Simpulan}

Berdasarkan hasil dan pembahasan analisis tingkat kognitif soal pada Bab Garis dan Sudut dan Segi Empat dan Segitiga pada Modul Pengayaan Matematika Kelas VII Semester II Terbitan Putra Nugraha, maka dapat disimpulkan bahwa soal-soal pada Modul Pengayaan Kelas VII Semester II Terbitan Putra Nugraha pada Bab Garis dan Sudut terklasifikasi C1 (8,5\%), C2 (46,8\%), C3 (44,7\%), C4 (0\%), C5 (0\%), C6 (0\%) dengan didominasi oleh soal-soal pada tingkat kognitif C2 (Memahami) dan C3 (Mengaplikasikan). Hal ini menunjukan bahwa sebaran tingkat kognitif soal pada Bab Garis dan Sudut masih belum merata atau belum bervariasi. Soal-soal pada Modul Pengayaan Kelas VII Semester II Terbitan Putra Nugraha pada Bab Segi Empat dan Segitiga terklasifikasi C1 (12,2\%), C2 $(8,2 \%)$, C3 $(79,6 \%)$, C4 $(0 \%)$, C5 (0\%), C6 (0\%) dengan didominasi oleh soal-soal pada tingkat kognitif C3 (Mengaplikasikan). Hal ini menunjukan bahwa sebaran tingkat kognitif soal pada Bab Garis dan Sudut masih belum merata atau belum bervariasi.

\section{Daftar Rujukan}

Alfarisi, R. S. (2019). Pengembangan Buku Pengayaan Menulis Teks Anekdot Bermuatan Cinta Tanah Air. Jurnal Kredo. 3(1), 102-115.

Ambar, A \& Nailatul, U. (2018). Hubungan Kemampuan Logika Matematika dengan Motivasi Siswa dalam Menyelesaiakan Soal Materi Bentuk Aljabar. Jurnal Penelitian Pendidikan Matematika, 2 (2): 82-91.

Anderson, L. W dan Krathwohl, D. R. (2010). Kerangka Landasan untuk Pembelajaran, Pengajaran dan Asesmen Revisi Taksonomi Pendidikan Bloom (Terjemahan oleh Agung Prihantoro). Yogyakarta: Pustaka Pelajar.

Effendi, R. (2017). Konsep Revisi Taksonomi Bloom Dan Implementasinya Pada Pelajaran Matematika SMP. Jurnal Ilmiah Pendidikan Matematika, 2(1),72-78.

Efriyanti, A. (2020). Analisis Soal Latihan Buku Teks Matematika Kurikulum 2013 Pada Materi Segiempat dan Segitiga Berdasarkan Teori Taksonomi Bloom Revisi. Universitas Bengkulu. Bengkulu.

Helmawati. (2019). Pembelajaran dan Penilaian Berbasis HOTS. Bandung: PT. Remaja Rosdakarya. 
Ihtifazhuddan R., Sunarsih S. S., \& Sutrisno. (2018). Desain Modul Pengayaan pada Mata Pelajaran Konstruksi Beton Bertulang Sesuai dengan Sni Beton untuk Meningkatkan Keaktifan dan Nilai Tiga Ranah Belajar Siswa Kelas XI Teknik Konstruksi Batu Beton SMK Negeri 2 Surakarta dengan Model Inquiry Learning. IJCEE, 4(1), 57-66.

Islah, Zamsir, Mukhsar, \& Rahman, A. (2019). Klasifikasi Soal Matematika Berdasarkan Taksonomi Anderson Di SMP Kota Kendari. Jurnal Pembelajaran Berpikir Matematika (Journal of Mathematics Thinking Learning), 4(2), 179-190.

Lasmiyati, L., \& Harta, I. (2014). Pengembangan Modul Pembelajaran untuk Meningkatkan Pemahaman Konsep dan Minat SMP. PYTHAGORAS: Jurnal Pendidikan Matematika, 9(2), 161-174.

Misbahuddin \& Hasan, I. (2014). Analisis Data Penelitian dengan Statistik. Jakarta: Bumi Aksara.

Peraturan Pemerintah Nomor 32 Tahun 2013 Tentang Standar Nasional Pendidikan.

Prasetya, I. Y. (2017). Analisis Soal-Soal pada Buku Ajar Matematika Kelas VII Ditinjau dari Taksonomi Bloom Revisi. Universitas Muhammadiyah Surakarta: Surakarta.

Setiyadi M. W., Ismail, \& Gani H. A. (2017). Pengembangan Modul Pembelajaran Biologi Berbasis Pendekatan Saintifik Untuk Meningkatkan Hasil Belajar Siswa. Journal of Educational Science and Technology, 3(2), 102-112.

Sugiyono. (2016). Metode Penelitian Pendidikan (Pendekatan Kuantitaif, Kualitatif, dan RED. Bandung: Alfabeta.

Widyaharti, M., Trapsilasiwi, D., \& Fatahillah, A. (2015). Analisis buku siswa matematika Kurikulum 2013 untuk Kelas X berdasarkan rumusan Kurikulum 2013. Kadikma, 6 (2), 173-184. 